T.-L. Chen MD PhD, C.-J. Lin MD, H.-S. Lai MD PhD,* W.-J. Chen MD PhD MPH, ${ }^{*}$ C.-C. Chao MD, C.-C. Liu MD PhD

\section{Anaesthetic manage- ments for conjoined twins with complex cardiac anomalies}

Purpose: To describe the perioperative assessment and anaesthetic management for surgical separation of three sets of conjoined twins with complex cardiac anomalies threatened with arterial desaturation and haemodynamic instability.

Clinical features: Three sets of conjoined twins, one omphaloischiopagus, one omphalopagus, and one thoraco-omphalopagus, were considered for separation during the perinatal or infantile period. Preoperative functional evaluation including continuous pulse oximetry, capnography, and cardiac electrophysiological studies were considered to be as important as anatomical evaluation of the cardiac anomalies and cross-circulation by angiography in assessing the feasibility of surgical separation. Ipsilateral infusion of prostaglandin $E_{l}$ and phenylephrine were applied to the cyanotic and healthy twins respectively, to restore arterial oxygenation intraoperatively and to avoid profound hypoxaemia.

Conclusion: Surgical separation and anaesthesia should be well planned and rehearsed before clinical deterioration of the weaker twin. Aggressive pharmacological intervention and understanding of the cross-circulation pathophysiology is necessary to manage critical situations during surgical separation and in the postoperative period.

\section{Key words}

ANAESTHESIA: paediatric;

CONGENITAL ANOMALY: cardiac;

TWINS: conjoined.

From the Department of Anaesthesia and *Department of Surgery, National Taiwan University Hospital, Taipei, Taiwan, Republic of China.

Address correspondence to: Dr. Ta-Liang Chen, Department of Anaesthesia, National Taiwan University Hospital, 7 Chung-Shan South Road, Taipei, Taiwan, 100, Republic of China.

Phone: (8862) 397-0800 (Ext 5515). Fax: (8862) 341-5736.

Accepted for publication June 28, 1996.
Objectif: Décrire l'évaluation périopératoire et la gestion anesthésique de la séparation chirurgicale de trois couples de jumeaux siamois porteurs d'anomalies cardiaques complexes susceptibles de désaturation artérielle et d'instabilité hémodynamique.

Éléments cliniques: Trois couples de jumeaux siamois, dont un omphaloischiopage, un omphalopage et un thoraco-omphalopage étaient programmés pour une séparation pendant la période périnatale ou infantile. L'évaluation fonctionnelle préopératoire dont l'oxygmétrie de pouls continue, la capnographie, et les épreuves électrophysiologiques cardiaques étaient considérées comme aussi importantes que l'évaluation anatomique des anomalies cardiaques et l'étude de la circulation croisée par angiographie pour décider de la faisabilité d'une séparation chirurgicale. Une perfusion homolatérale de protaglandine $E_{l}$ et de phényléphrine ont été administrées respectivement au jumeau cyanotique et au jumeau sain pour restaurer l'oxygénation artérielle pendant l'intervention et pour éviter l'hypoxémie profonde.

Conclusion: La séparation chirurgicale et l'anesthésie doivent être bien planifiées et répétées avant la détérioration du jumeau faible. Une intervention pharmacologique agressive et une connaissance de la physiopathologie de la circulation croisée sont essentielles pour la gestion des situations critiques pendant l'intervention pour séparation ainsi qu'à la période postopératoire.

Successful separation of conjoined twins usually is not feasible because of the complexity of organ sharing and the severity of the associated anomalies. However, they continue to fascinate physician and general public alike. There are numerous reports of the surgical separation of conjoined twins, and many aspects concerning the anaesthetic management have been discussed..$^{1-4}$ but there are no reports the general principles of handling twins with severe cardiac anomalies. We describe our experience with three sets of critical twins with complex cardiac anomalies in one baby of each twin. Arterial desaturation and/or intractable congestive heart failure forced rescue of the twins with early surgical separation. 
Specific problems concerning preoperative evaluation, maintenance of anaesthesia and pharmacological intervention to maintain arterial oxygenation during surgical separation are discussed.

\section{Case reports}

Case \#1

Female omphalo-ischiopagus tetrapus twins were born by Caesarean section at 37 wk gestation and admitted to hospital within $24 \mathrm{hr}$ after birth. The Apgar scores at one minute were 6 and 7 at five minutes. The combined weight of the twins was $3800 \mathrm{~g}$. The bigger $\left(A_{1}\right)$ was pinkish with good activity and the second $\left(B_{1}\right)$ was smaller, cyanotic and tachypnoeic, with an appearance of micrognathia, low-set ears, web neck, and cleft palate (Pierre Robin Syndrome-like appearance). They were joined from the subxiphoid to the lumbosacral region and shared a single umbilical cord (Figure 1). Chest $x$ ray revealed a normal twin $A_{1}$, while twin $B_{1}$ had severe diaphragmatic hernia, plcural effusion, and left lung hypoplasia. Cardiac catheterization and echocardiography showed twin $A_{t}$ with patent ductus arteriosus, patent foramen ovale and mild coarctation of aorta. However, complex cardiac anomalies with hypogenesis of the common ventricle, pulmonary stenosis, endocardial cushion defect and pericardial effusion were demonstrated in twin $B_{1}$. Liver scan and angiography presented a tight linkage of the liver at its mid-portion for $7 \mathrm{~cm}$ in the longitudinal axis with independent vascular and biliary systems. Gastrointestinal series revealed a separate alimentary tract in its upper part and a communication in the rectum. Splanchnic angiography demonstrated abundant cross-circulation through the superior mesenteric and internal iliac artery systems between the babies. The pelvis, external genitalia and anus were in one with separate spinal columns.

Twin $\mathrm{B}_{1}$ was persistently cyanotic $\left(\mathrm{SpO}_{2} 75-77 \%\right)$, tachypnoeic, and in congestive heart failure state with sinus tachycardia (heart rate 200 beats $\cdot \mathrm{min}^{-1}$ ) during admission despite digitalization. Conjoined survival of the twins was deemed impossible, the committee for combined care recommended surgical intervention earlier than anticipated. The operation was performed when the twins were 14-days-old, weighing $4200 \mathrm{~g}$. A \#22 gauge intravenous cannula was inserted on the dorsum of the hand of each baby the day before surgery. Atropine $0.05 \mathrm{mg}$ im and $10 \mathrm{mg}$ hydrocortisone iv were administrated as premedication and prophylaxis for adrenal insufficiency. ${ }^{5}$ A team for extracorporeal cardiopulmonary bypass was available during the operation. Fresh whole blood from the parents was prepared for intraoperative blood replacement and ECG, rectal

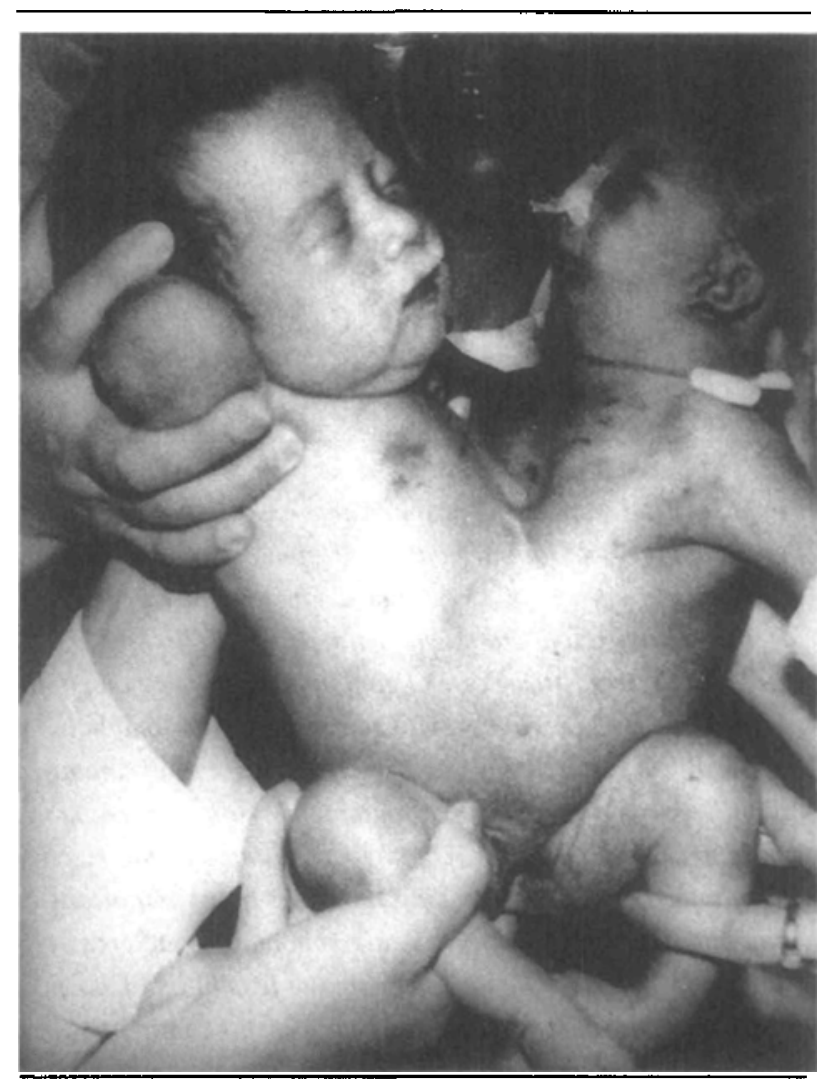

FIGURE 1 The omphalo-ischiopagal conjoined twins ( $A_{1}$, the left; $B_{1}$, the right) at 14-days before separation.

temperature, and pulse oximetry were monitored before induction of anaesthesia. After $10 \mathrm{~min}$ preoxygenation to both twins, anaesthesia was induced with $15 \mathrm{mg}$ thiopentone and $5 \mathrm{mg}$ succinylcholine iv to twin $\mathrm{A}_{1}$ and tracheal intubation was performed in rapid sequence. Awake orotracheal intubation was performed with difficulty in twin $B_{1}$ because of its abnormal craniofacial appearance. Immediately after intubation, high air-way resistance with restricted lung expansion was noted in twin $B_{1}$. In both babies, pulmonary ventilation was achieved using two ventilators (Servo 900C, Siemens, Sweden). Oesophageal stethoscopes with temperature probes, and end-tidal $\mathrm{CO}_{2}$ were monitored in each twin. In twin $A_{1}$, muscle relaxation was with $2.5 \mathrm{mg}$ atracurium and anaesthesia was maintained with $150 \mu \mathrm{g}$ fentanyl initially and nitrous oxide $50 \%$, oxygen $100 \%$ was given to twin $B_{1}$. After induction, arterial cannulae were inserted in both babies through the right radial artery and central venous pressure (CVP) was monitored via cannulation of the right internal jugular vein in twin $A_{1}$ and via a venous cut-down of the external jugular vein in twin $B_{1}$.

During dissection of the liver, $\mathrm{SpO}_{2}$ of twin $\mathrm{B}_{1}$ decreased from 85 to $68 \%$. Three minutes later, the $\mathrm{SpO}_{2}$ 
TABLE Intraoperative haemodynamic variables, oxygenation and anaesthetic management for three sets of conjoined twins $\left(A_{1} B_{1}, A_{2} B_{2}\right.$, and $\left.A_{3} B_{3}\right)$ with complex congenital cardiac anomalies.

\begin{tabular}{|c|c|c|c|}
\hline & $\begin{array}{l}\text { Twin } \\
A_{1}: B_{1}\end{array}$ & $\begin{array}{c}\text { Twin } \\
\mathrm{A}_{2}: \mathrm{B}_{2}\end{array}$ & $\begin{array}{l}\text { Twin } \\
A_{3}: B_{3}\end{array}$ \\
\hline \multicolumn{4}{|l|}{ Mean arterial pressure; $\mathrm{mmHg}$} \\
\hline - before induction & $60: 50$ & $58: 52$ & $70: 65$ \\
\hline - during separation & $51: 45$ & $50: 48$ & $62: 50$ \\
\hline - after prostaglandin $E_{1}$ and phenylephrine & $62: 48$ & $55: 50$ & $68: 55$ \\
\hline \multicolumn{4}{|l|}{ Arterial oxygenation, $\mathrm{PaO}_{2} ; \mathrm{kPa}$} \\
\hline - before induction & $13.1: 6.6$ & $12.6: 6.2$ & $11.7: 6.4$ \\
\hline - during separation & $8.2: 4.6$ & $8.7: 3.7$ & $8.3: 4.3$ \\
\hline - after prostaglandin $E_{1}$ and phenylephrine & $16.6: 8.5$ & $14.8: 7.1$ & $13.0: 7.3$ \\
\hline \multicolumn{4}{|l|}{$\mathrm{O}_{2}$ saturation by pulse oximetry, $\mathrm{SpO}_{2} ; \%$} \\
\hline - before induction & $95-98: 77-80$ & $94-97: 68-70$ & $97-99: 70-78$ \\
\hline - during separation & $90-91: 65-68$ & $90-94: 46-50$ & $90-91: 60-65$ \\
\hline - after prostaglandin $E_{1}$ and phenylephrine & $98-99: 90-92$ & $96-98: 80-85$ & $97-99: 80-85$ \\
\hline Infusion of prostaglandin $\mathrm{E}_{1} \mathrm{ng} \cdot \mathrm{kg}^{-1} \cdot \mathrm{min}^{-1}$ & $-: 10-40$ & $-: 25-40$ & $-: 20-40$ \\
\hline Infusion of phenylephrine; $\mu \mathrm{g} \cdot \mathrm{kg}^{-1} \cdot \mathrm{min}^{-1}$ & $0.1-0.3:-$ & $0.2-0.3:-$ & $0.1:-$ \\
\hline
\end{tabular}

of twin $A_{1}$ gradually decreased from 98 to $91 \%$. The blood pressure of the twins decreased from $78 / 52$ to $65 / 44 \mathrm{mmHg}$ in twin $\mathrm{A}_{1}$ and from $66 / 42$ to $55 / 40 \mathrm{mmHg}$ in twin $B_{1}$. After blood transfusion and dopamine infusion (3-5 $\left.\mu \mathrm{g} \cdot \mathrm{kg}^{-1} \cdot \mathrm{min}^{-1}\right)$, the blood pressure was restored but the $\mathrm{SpO}_{2}$ remained poor. In anticipation of discontinuing the cross-circulation with derangement between the pulmonary and systemic vascular resistance, prostaglandin $\mathrm{E}_{1} \quad 10-40 \mathrm{ng} \cdot \mathrm{kg}^{-1} \cdot \mathrm{min}^{-1}$ was given via the central venous infusion to twin $B_{1}$ to dilate the pulmonary vessels and to decrease pulmonary vascular resistance. Phenylephrine $0.1-0.3 \mu \mathrm{g} \cdot \mathrm{kg}^{-1} \cdot \mathrm{min}^{-1}$ was also given to twin $A_{1}$ to increase peripheral vascular resistance. The $\mathrm{SpO}_{2}$ of both twins increased from 91 to $99 \%$ in twin $A_{1}$, and from 68 to $92 \%$ in twin $B_{1}$ and remained stable (Table). Total blood transfusion to twin $A_{1}$ was $150 \mathrm{ml}$ and $80 \mathrm{ml}$ to $B_{1}$. Sodium bicarbonate 7 $\mathrm{mEq}$ was given to each baby. Another $5 \mathrm{mg}$ hydrocortisone iv was given to each baby after separation. Throughout the operation, the condition of twin $A_{1}$ remained stable while that of twin $B_{1}$ continued to deteriorate after separation due to the complicated cardiac anomalies and pulmonary hypoplasia. After vigorous cardiopulmonary resuscitation, her condition remained poor and she died two hours after separation. The general condition of twin $A_{1}$ remained stable postoperatively and the trachea was extubated $48 \mathrm{hr}$ later. A number of procedures for debridement and skin grafts were required to facilitate wound healing. At $41 / 2 \mathrm{mo}$, twin $A_{1}$ went home with bottle feeding and in healthy condition.

\section{Case \#2}

A male omphalopagus tetrapus was transferred to our neonatal intensive care unit $16 \mathrm{hr}$ after delivery by
Caesarean section due to premature rupture of the membranes at $36 \mathrm{wk}$ gestation. The Apgar scores were 3 at one minute and 8 at five minutes with a combined weight $5500 \mathrm{~g}$. They were joined from the lower sternum to the umbilicus sharing a single umbilical cord with freely movable extremities. Twin $\mathrm{A}_{2}$ was relatively healthy, while twin $\mathrm{B}_{2}$ was tachypnoeic, cyanotic $\left(\mathrm{SpO}_{2}\right.$ 75-80\%) with mild subcostal retraction (Figure 2). Echocardiogram and cardiac catheterization revealed a normal heart with patent foramen ovale in twin $\mathbf{A}_{2}$. Complex cyanotic congenital heart disease, including right atrial isomerism, total anomalous pulmonary venous return (supracardiac type), endocardial cushion defect (complete form), double outlet of right ventricle with pulmonary atresia, patent ductus arteriosus $(3 \mathrm{~mm}$ diameter), and right aortic arch were noted in twin $B_{2}$. The CAT scan demonstrated fused livers in a normal position. Angiography revealed communication of the coeliac trunk and superior mesenteric arteries with an independent portal system. Intravenous pyelography showed independent urogenital tracts. The twins were well during the course of evaluation except that the $\mathrm{SpO}_{2}$ in twin $\mathrm{B}_{2}$ declined progressively from 80 to $70 \%$ in spite of continuous positive airway pressure. After detailed evaluation, the committee of combined care suggested surgical separation before further deterioration in twin $\mathrm{B}_{2}$.

The operation was performed when the twins were 30-days-old and weighing $6600 \mathrm{~g}$. They were premedicated with $0.05 \mathrm{mg}$ atropine im and $10 \mathrm{mg}$ hydrocortisone $i v$ respectively. A \#22 gauge intravenous catheter was inserts in the dorsum of the hand of each twin on the day before surgery. On arrival in the operating room, each twin was monitored by precordial stethoscope, two 


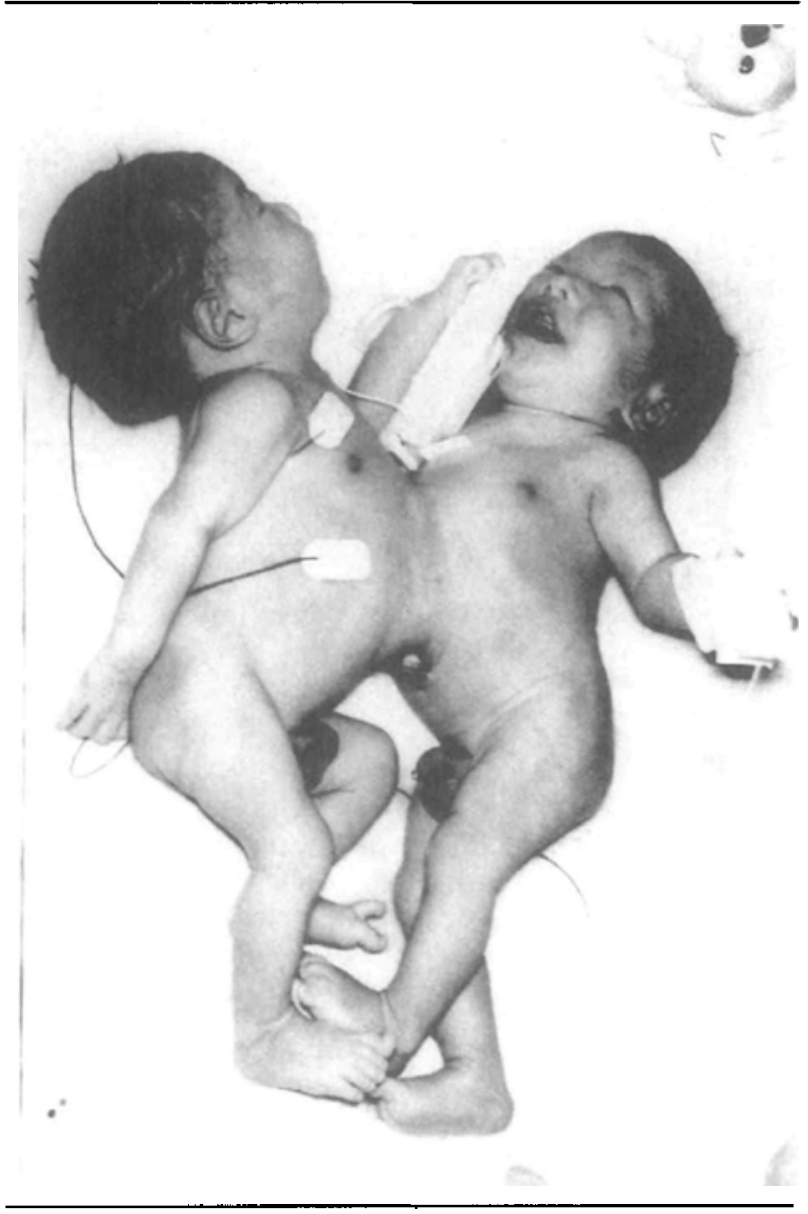

FIGURE 2 The omphalopagal conjoined twins $\left(A_{2}\right.$, the left; $B_{2}$, the righi) at 30 days before separation.

sets of pulse oximeters at the thumb and toe, ECG leads II and $V_{5}$, and noninvasive blood pressure cuff. After five minutes preoxygenation, general anaesthesia was induced with $5 \mathrm{mg} \cdot \mathrm{kg}^{-1}$ thiopentone, and $1.5 \mathrm{mg} \cdot \mathrm{kg}^{-1}$ succinylcholine to twin $A_{2}$ followed by nasotracheal intubation. Orotracheal intubation was performed smoothly in twin $\mathrm{B}_{2}$ without further medication. The radial artery and right internal jugular vein were cannulated after induction and were continuously monitored. Anaesthesia was maintained with a continuous infusion of fentanyl $\left(10 \mu \mathrm{g} \cdot \mathrm{kg}^{-1} \cdot \mathrm{hr}^{-1}\right)$ and isoflurane $0.4-1.0 \%$ in oxygen $60 \%$ for each twin. Muscle relaxation was provided by incremental doses of atracurium. A common fused liver was found and was separated. Replacement of blood loss was titrated to maintain CVP and haematocrit values in each baby. During the dissection of the conjoined liver, the $\mathrm{SpO}_{2}$ gradually decreased from 85 to $46 \%$ in twin $B_{2}$, and from 99 to $94 \%$ in twin $A_{2}$ suggesting intracardiac shunt in twin $A_{2}$ and crosscirculation from twin $B_{2}$ to twin $A_{2}$. Prostaglandin $E_{1} 40$ $\mathrm{ng} \cdot \mathrm{kg}^{-1} \cdot \mathrm{min}^{-1}$ through the central venous line was infused into twin $\mathrm{B}_{2}$ to promote pulmonary blood flow. Phenylephrine $0.2-0.3 \mu \mathrm{g} \cdot \mathrm{kg}^{-1} \cdot \mathrm{min}^{-1}$ was infused in twin $A_{2}$ to increase peripheral vascular resistance and recruit blood flow from twin $A$ to twin $B$. The $\mathrm{SpO}_{2}$ of twin $B_{2}$ improved from 46 to $85 \%$ and from 94 to $98 \%$ in twin $\mathrm{A}_{2}$ within five minutes (Table). The operating time was $2 \frac{1 / 2}{h r}$ and the total blood transfused to twin $\mathrm{A}_{2}$ was $50 \mathrm{ml}$ and $20 \mathrm{ml}$ to twin $B_{2}$. Throughout the operation, the haemodynamic status and $\mathrm{SpO}_{2}$ of twin $\mathrm{A}_{2}$ remained good and the trachea was extubated with an uneventful postoperative course. However, maintenance of $\mathrm{SpO}_{2}(75-88 \%)$ of twin $\mathrm{B}_{2}$ depended on the infusion of prostaglandin $\mathrm{E}_{1}\left(20-40 \mathrm{ng} \cdot \mathrm{kg}^{-1} \cdot \mathrm{min}^{-1}\right)$ postoperatively due to the complex cardiac anomalies. He was sent to the ICU for further ventilatory support. Due to progressive decrease of $\mathrm{SpO}_{2}$ from 80 to $70 \%$ despite increasing doses of prostaglandin $E_{1}$, twin $B_{2}$ received palliative corrective cardiac surgery by a vertical pulmonary vein-to-left atrial appendage anastomosis 12 days after separation. After surgery, $\mathrm{SpO}_{2}$ improved from 70 to $90 \%$ but still was prostaglandin $E_{1}$-dependent. However, severe bradycardia with repeated attacks of pneumonia and disseminated intravascular coagulopathy complicated the postoperative course and he died at one month after separation at the age of two months.

\section{Case \#3}

A male thoraco-omphalopagus tetrapus delivered by Caesarean section, birth weight $5100 \mathrm{~g}$, was referred at the age of 25 days. The twins were joined from midsternum to a common umbilicus. The larger twin $A_{3}$ was healthy but twin $B_{3}$ was mildly cyanotic and tachypnoeic (Figure 3). Electro-cardiogram of twin $B_{3}$ revealed a normal $P$ wave, followed by two closely spaced but separate, narrowed QRS complexes. In twin $\mathrm{A}_{3}$, the $\mathrm{P}$ wave presented with an indeterminate axis but with similar paired QRS complexes. Cardiac electrophysiological studies revealed both twins had their own functioning sinoatrial nodes although that of twin $\mathbf{B}_{3}$ dominated twin $\mathrm{A}_{3}$ through an isolated atrial electromyocardial continuity between the twins (Figure 4). Echocardiography and cardiac catheterization showed a side-by-side, close relationship of the twins heart. The left atrium of twin $A_{3}$ lay parallel and to the left ventricle of twin $B_{3}$ with no evidence of cross-circulation or shared chambers. There was a small ventricular septal defect in twin $\mathbf{A}_{3}$. Complex intracardiac anomalies including severe pulmonary stenosis, ventricular septal defect, tricuspid regurgitation, patent ductus arteriosus, and patent foramen ovale with right to left shunt were demonstrated in twin $B_{3}$. Selective angiography and imaging studies, (CAT and MRI), showed that the livers were conjoined 


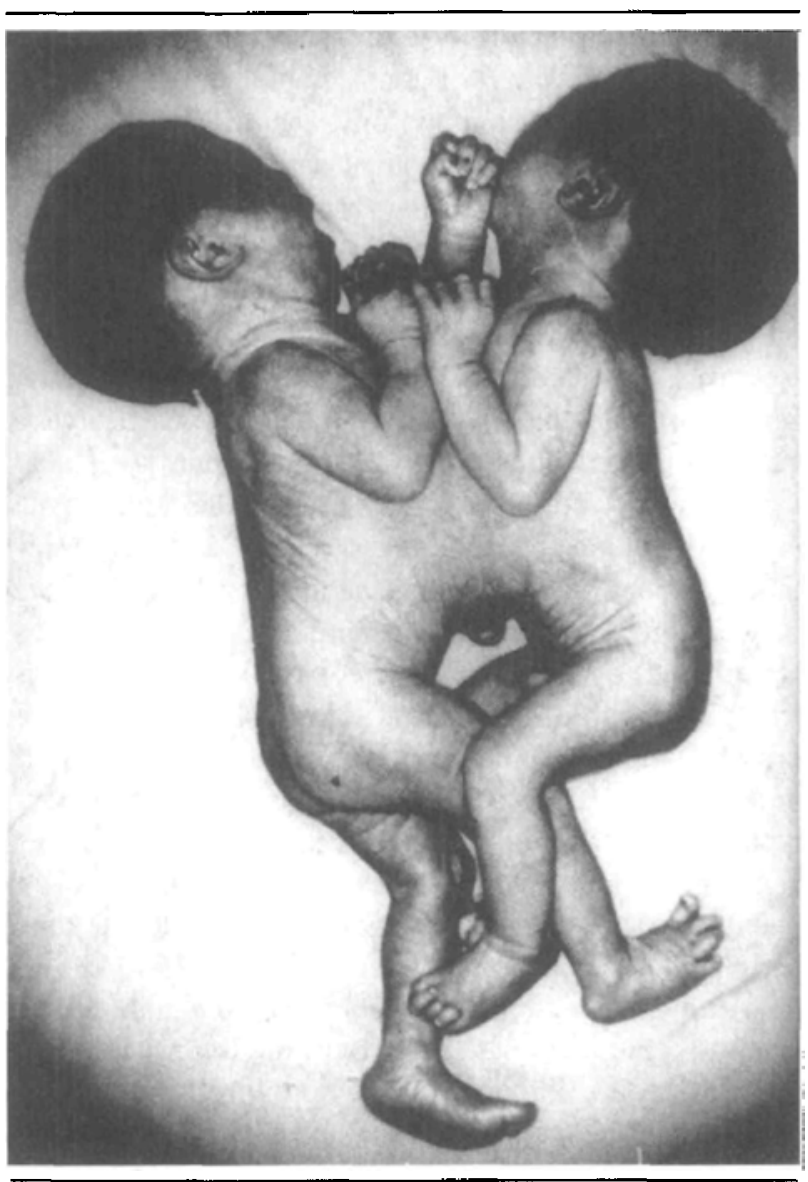

FIGURE 3 The thoraco-omphalopagal conjoined twins $\left(\mathrm{A}_{3}\right.$, the right; $\mathbf{B}_{3}$, the left) at 5 months before separation.

with separate biliary systems. The gastrointestinal and urogenital systems were separate and normal.

After detailed evaluation, the committee for combined care suggested supportive treatment to gain weight because the twins' clinical condition was stable. Cyanosis and aspiration pneumonia occurred once in twin $B_{3}$ at two months but he recovered after aggressive chest care. At five months, severe and progressive heart failure with arterial desaturation $\left(\mathrm{SpO}_{2}\right.$ decreased from 72 to $40-45 \%$ ) in twin $B_{3}$ initiated the decision for emergency separation. On the morning of surgery, a \#22 gauge iv route was setup through each baby's arm. Hydrocortisone, $10 \mathrm{mg} i \mathrm{v}$, was administered to each twin before induction of anaesthesia. After preoxygenation for five minutes, anaesthesia was induced in twin $\mathrm{A}_{3}$ with $10 \mathrm{mg}$ ketamine, $0.05 \mathrm{mg}$ atropine, and $10 \mathrm{mg}$ succinylcholine $i v$ to facilitate intubation. Nasotracheal intubation was performed without difficulty in twin $A_{3}$ and in twin $B_{3}$ with $3.5 \mathrm{~mm}$ uncuffed tubes without further anaesthetic. Anaesthesia was maintained with 150 $\mu \mathrm{g}$ fentanyl, $0.6 \mathrm{mg}$ pancuronium, nitrous oxide $50 \%$

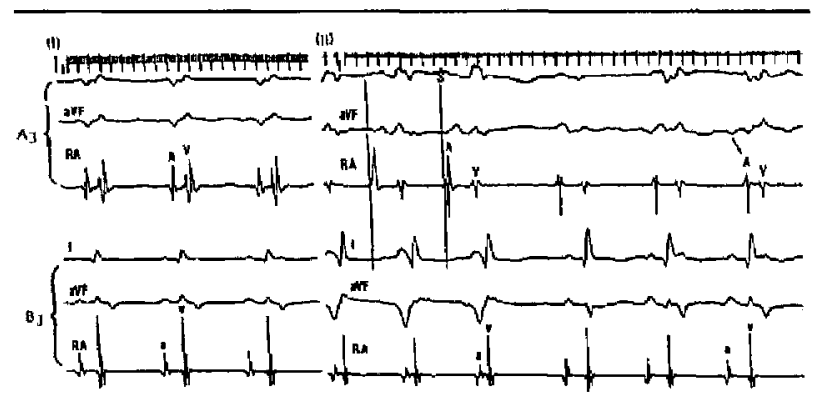

FIGURE 4 Cardiac electrophysiological studies by simultaneous intracardiac recordings for the twin $A_{3}$, and $B_{3}$. Top trace is time-scale for recording ( $25 \mathrm{~mm} \cdot \mathrm{sec}^{-1}$ ). Three lines of recording represent lead I, aVF and right atrial tracing respectively. (I) The atrial depolarization of twin $B_{3}(a)$ induced atrial depolarization of twin $A_{3}(A)$ with separate ventricular depolarization of both twins ( $V$ and $V$ ). (II) After termination of right atrial pacing(S) in twin $A_{3}$, the atrial activity of twin $B_{3}(a)$ appeared earlier than that of twin $A_{3}(A)$ and paced twin $A_{3}$ (arrow) very soon.

and isoflurane $0.5-1.0 \%$ in twin $A_{3}$, but only $100 \%$ oxygen was given to twin $B_{3}$. Anaesthesia was supplemented with fentanyl infusion $\left(10-20 \mu \mathrm{g} \cdot \mathrm{kg}^{-1} \cdot \mathrm{hr}^{-1}\right)$ in each twin. The lungs were mechanically ventilated with separate ventilators and muscle relaxation was provided by incremental doses of pancuronium. Monitors included ECG (leads II and $V_{s}$ ), oesophageal stethoscope, oesophageal and rectal temperature probes, pulse oximetry, capnography, radial artery and internal jugular venous cannulations for each twin.

At operation, a common pericardium with a fibromuscular band at the atrioventricular groove between the two hearts assured the feasibility of surgical separation. During dissection of the conjoined liver, severe arterial desaturation $\left(\mathrm{SpO}_{2} 85\right.$ to $\left.65 \%\right)$ with hypotension (BP $84 / 60$ to $60 / 45 \mathrm{mmHg}$ ) occurred in twin $B_{3}$. After careful titration of blood transfusion through the central venous route the $\mathrm{SpO}_{2}$ was not restored until infusion of prostaglandin $\mathrm{E}_{1} 20-40 \mathrm{ng} \cdot \mathrm{kg}^{-1} \cdot \mathrm{min}^{-1}$ to twin $B_{3}$ and $0.1 \mu \mathrm{g} \cdot \mathrm{kg}^{-1} \cdot \mathrm{min}^{-1}$ phenylephrine to twin $\mathrm{A}_{3}$ (Table). An aortopulmonary shunt was established between the aorta and the right pulmonary artery in twin $B_{3}$. The total time for the operation lasted for 91/2 hr. Intraoperative fluid was infused using 10-15 $\mathrm{ml} \cdot \mathrm{kg}^{-1} \cdot \mathrm{hr}^{-1}$ isotonic solution for each twin. The amount of transfusion was $35 \mathrm{ml}$ in twin $\mathrm{A}_{3}$ and $25 \mathrm{ml}$ in twin $B_{3}$. The haematocrit ranged from 55 to $61 \%$ and haemoglobin from 15.5 to $16.1 \mathrm{~g} \cdot \mathrm{dl}^{-1}$. After surgery, twin $B_{3}$ developed intractable bradycardia, bypoxaemia and severe $\mathrm{CO}_{2}$ retention and died of cardiopulmonary insufficiency five hours later while twin $\mathrm{A}_{3}$ survived with a complicated postoperative course. Repeated fungal infections and diaphragmatic defects prolonged the 
need for ventilatory support. After intensive treatment for five months, he was transferred to the ward and was discharged home with good activity and oral feeding. He was readmitted due to aspiration pneumonia and cyanosis and he died of disseminated intravascular coagulopathy two days later, seven months after separation.

\section{Discussion}

The complexity of separating conjoined twins is a challenge in medical, surgical and ethical aspects. ${ }^{6}$ Modern diagnostic, surgical and anaesthetic techniques allow all newly delivered conjoined twins to be regarded as potentially correctable and they deserve prompt investigation to determine the feasibility of separation. The three sets of conjoined twins that we describe demonstrated severe arterial desaturation due to complex cardiac anomalies in one twin. Management for separation included the careful preanaesthetic evaluation, perioperative monitoring and aggressive cardiovascular intervention.

A major concern deterring attempts at surgical separation is the high prevalence of congenital anomalies and communications in the cardiovascular and/or central venous systems in conjoined twins. ${ }^{7-9}$ Thoracopagus, for example, represents $75 \%$ of cases reported and $75 \%$ have conjoined hearts often making surgical division impossible. ${ }^{10-12}$ Understanding the pathogenesis of the intracardiac anomalies is fundamental. Preoperative functional evaluation by cardiac electro-physiological studies, continuous monitoring of $\mathrm{O}_{2}$ saturation, and capnography may be as important as anatomical studies including echocardiography, contrast tomography, and magnetic resonance imaging in the accurate assessment of joining and the feasibility of separation. The cardiovascular anatomy was outlined preoperatively by cardiac catheterization and selective angiography and demonstrated the complex intra-cardiac anomalies and the dynamic cross-circulation of the twins. However, close interaction among the individual intracardiac shunts, cross-circulation between the twins, and the haemodynamic alterations during separation make the clinical situation more complicated and unexpected.

O'Neill et al. reported a survival rate of $50 \%$ receiving neonatal separation and $90 \%$ in those separated after separation at four months. ${ }^{13}$ As long as clinical conditions permits, delayed separation at 6-12 mo is recommended. Emergency surgical separation should be undertaken only when the clinical condition of one twin is deteriorating and threatens the survival of both. ${ }^{14}$ It is obligatory to observe for signs, such as decreasing appetite and loss of activity, oliguria with cardiomegaly, pericardial or pleural effusion, and hypotension with tachycardia, to recognise decompensation in the weaker twin. Pulse oximetry is of considerable help in monitoring peripheral perfusion and oxygenation and may provide the earliest sign of decompensation.

The major problems during surgery were frequent and abrupt alterations in haemodynamic function and tissue oxygenation. Adequate fluid therapy and dopamine infusion may prevent inadequate tissue perfusion. However, despite careful monitoring of temperature, CVP, arterial blood gases, glucose, electrolytes, haemogram, coagulation profile and volume replacement, unexpected hazards may occur. Alteration to the cross-circulation, establishment of independent cardiopulmonary status after separation, and imbalance between the pulmonary and systemic vascular resistance contributed to the clinical complexity. In the twins who had right-to-left intracardiac shunt, we gave prostaglandin $E_{1}$ to the cyanotic twin to reduce the pulmonary vascular resistance. The increased pulmonary blood flow antagonized the endogenous vasoconstrictors and improved $\mathrm{SpO}_{2}{ }^{15-18}$ Meanwhile, infusion of phenylephrine to the healthy twin could elevate the total peripheral resistance preventing shunting of blood volume from the cyanotic twin converted the right-to-left shunt to a bidirectional shunt. Both the timing and dose of infusion are important for improving $\mathrm{SpO}_{2}$ during separation. Phenylephrine usually can be discontinued immediately after separation while the need for prostaglandin $E_{1}$ postoperatively depends on the adequacy of pulmonary blood flow in the cyanotic twin. Early and adequate pharmacological intervention including sympathomimetic and parasympatholytic agents, vasopressors and vasodilators, should be prepared before surgery and aggressively administered to prevent cardiovascular collapse during and after separation. Postoperatively, ventilatory support was given to the survivors. Most twins with severe cardiac anomalies may not survive independently after separation. We experienced two immediate postoperative deaths in these three sets of conjoined twins in spite of vigorous cardiopulmonary resuscitation.

In summary, we described the perioperative management for the surgical separation of three sets of conjoined twins with complex cardiac anomalies. Accurate preoperative understanding of the cardiovascular pathophysiology, aggressive pharmacological intervention, careful maintenance of physiological homeostasis, and close coordination between members of the separation teams are essential for a successful outcome.

\section{Acknowledgments}

The authors recognize Dr. Mei-Hwan Wu for permission to reproduce and interpretation of cardiac electro- 
physiological data (twins $A_{3} B_{3}$ ). Also, we thank Ms. Hsiu-Pei Lai for her help in preparing the manuscript.

\section{References}

1 Hoyle RM. Surgical separation of conjoined twins. Surg Gynecol Obstet 1990; 170: 549-62.

2 Chao C-C, Susetio L, Luu K-W, Kwan W-F. Anaesthetic management for successful separation of tripus ischiopagal conjoined male twins. Can J Anaesth 1980; 27: 565-70.

3 Harper RG, Kenigsberg K, Sia CG, Horn D, Stern D, Bongiovi $V$. Xiphopagus conjoined twins: a 300-year review of the obstetric, morphopathologic, neonatal, and surgical parameters. Am J Obstet Gynecol 1980; 137: 617-29.

4 Diaz JH, Furman EB. Perioperative management of conjoined twins. Anesthesiology 1987; 67: 965-73.

5 Aird I. The conjoined twins of Kano. BMJ 1954; 1 : 831-7.

6 Rejjal A-LR, Nazer HM, Abu-Osba YK, Rifai A, Ahmed S. Conjoined twins: medical, surgical, and ethical challenges. Aust NZ J Surg 1992; 62: 287-91.

7 Bloch EC, Karis JH. Cardiopagus in neonatal thoracopagus twins: anesthetic management. Anesth Analg 1980; 59: 304-7.

8 Antonelli D, Shmilovitz L, Dharan $M$. Conjoined hearts. British Heart Journal 1986; 56: 486-8.

9 Wong KC, Ohmura A, Roberts TH, Webster LR, Cook GL. Anesthetic management for separation of craniopagus twins. Anesth Analg1980; 59: 883-6.

10 Nichols BL, Blattner RJ, Rudolph AJ. General clinical management of thoracopagus twins. Birth Defects 1967; 3: 38-51.

11 Marin-Padilla M, Chin AJ, Marin-Padilla TM. Cardiovascular abnormalities in thoracopagus twins. Teratology 1981; 23: 101-13.

12 Patel R, Fox K, Dawson J, Taylor JFN, Graham GR. Cardiovascular anomalies in thoracopagus twins and the importance of preoperative cardiac evaluation. British Heart Journal 1977; 39: 1254-8.

13 O'Neill JA Jr, Holcomb GW III, Schnauffer L, et al. Surgical experience with thirteen conjoined twins. Ann Surg 1988; 208: 299-312.

14 Campbell GD, Brown SW, Anderson M, Anderson PG. Separation of conjoined twins. Aust NZ J Surg 1990; 60: 59-61.

15 Neutze JM, Starling MB, Elliott RB, Barratt-Boyes BG. Palliation of cyanotic congenital heart disease in infancy with E-type prostaglandins. Circulation 1977; 55 : 238-41.

16 Pitlick P, French JW, Maze A, Kimble KJ, Ariagno RL, Reitz $B A$. Long-term low-dose prostaglandin $\mathrm{E}_{1}$ administration. J Pediatr 1980; 96: 318-20.

17 Coceani F, Olley PM, Lock JE. Prostaglandins, ductus arteriosus, pulmonary circulation: current concepts and clinical potential. Eur J Clin Pharmacol 1981; 18: 75-81.

18 Chen T-L, Lee Y-T, Wang M-J, Lee J-M, Lee Y-C, Chu S$H$. Endothelin-1 concentrations and optimisation of arterial oxygenation and venous admixture by selective pulmonary artery infusion of prostaglandin $E_{1}$ during thoracotomy. Anaesthesia 1996; 51: 422-6. 